\title{
Urban Vertical Farming as an Example of Nature-Based Solutions Supporting a Healthy Society Living in the Urban Environment
}

\author{
Anna Zaręba ${ }^{1, *}$, Alicja Krzemińska ${ }^{1}$ and Renata Kozik ${ }^{2}$ D \\ 1 Faculty of Earth Sciences and Environmental Management, University of Wrocław, 50-137 Wrocław, Poland; \\ alicja.krzeminska@uwr.edu.pl \\ 2 Faculty of Civil Engineering, Cracow University of Technology, 31-155 Kraków, Poland; rkozik@pk.edu.pl \\ * Correspondence: anna.zareba@uwr.edu.pl
}

\section{check for} updates

Citation: Zaręba, A.; Krzemińska, A.; Kozik, R. Urban Vertical Farming as an Example of Nature-Based Solutions Supporting a Healthy Society Living in the Urban Environment. Resources 2021, 10, 109. https://doi.org/10.3390/ resources10110109

Academic Editors: Peter Cornelis Roebeling, Laura Wendling, Teresa Fidélis and Anna Stahlbrost

Received: 17 July 2021

Accepted: 21 October 2021

Published: 25 October 2021

Publisher's Note: MDPI stays neutral with regard to jurisdictional claims in published maps and institutional affiliations.

Copyright: (c) 2021 by the authors. Licensee MDPI, Basel, Switzerland. This article is an open access article distributed under the terms and conditions of the Creative Commons Attribution (CC BY) license (https:// creativecommons.org/licenses/by/ $4.0 /)$.

\begin{abstract}
The subject of the article concerns vertical urban farms that play an important role in naturebased solutions and ecosystem services for the city. In the face of a changing climate, progressive environmental degradation, and the related loss of agricultural land, vertical farms can be seen as an alternative to traditional agriculture. Woven into the blue-green infrastructure of cities, they may not only constitute a base for food production, but can also create a new valuable ecological, social, and economic hub in contemporary cities, changed by the COVID-19 pandemic. The objective of this paper is to show whether it is possible to introduce various functions which support ecosystem and social services, and whether they affect measurable benefits for urban residents in a large-scale system of solutions in the field of vertical urban agriculture. This research shows that urban vertical farms can perform many functions and bring diverse benefits to the inhabitants of cities. In a multi-scale system, they allow for the creation of patchwork connections, which stabilise a specific city biome in the vertical space.
\end{abstract}

Keywords: urban vertical farming; nature-based solutions; multi-functional vertical farms; green roofs; green facades

\section{Introduction \\ 1.1. General Research Background}

In 2015, more than half of the world and nearly three-quarters of the European population lived in cities or large agglomerations. In 2050, the proportion of the population living in urban areas around the world would, according to the UN forecast, will be more than $66 \%$, and $82 \%$ in Europe. Intensive urbanisation is not related to the development and quality of urban greenery. New areas are occupied, pollution increases, the surface area of forests is shrinking, erosion is intensified, and there is fragmentation of habitats which affects the reduction in biodiversity. The ecological function of greenery largely depends on the size of nature hubs, resilience, ecological linkages, and on the resistance of plant habitats to changes in the natural environment. Despite the important role played by urban ecosystems, they are exposed to the growing destruction of the ever-expanding city. In urban areas, where structures and spatial planning are dynamically transformed, there is a need to explore the possibility of introducing greenery in new spatial systems.

Nowadays, we observe dynamic population growth in the world, especially in the developing world, such as Africa, Asia, and South America. The UN estimates that over 21 billion people will live on Earth by the year 2100. In 2050, the percentage of the population living in urban areas in the world will be $66 \%$ and $82 \%$ in Europe, according to UN forecasts [1]. Rapid population growth naturally translates into food demand. Currently, $80 \%$ of the world's arable land is used, while the remaining $20 \%$ is wasteland, whose cultivation potential has virtually disappeared due to poor land management in 
recent decades. Thus, intensive urbanisation, population migrations to cities, and scarcity of arable lands give rise to the need to implement new solutions in the field of bio-architecture and agro-urban planning $[2,3]$. The human population, who are struggling with climate change, must create a new quality of space, which will not only maintain the environment's sustainability, but will also improve its quality.

Currently, in the era of COVID-19, the broadly understood safety of urban residents has acquired a new meaning and sense in a multidimensional system. The implementation of modern smart solutions based on information and communication technologies may result in the emergence of new practical solutions in the field of shaping new, safe green areas, fulfilling a production function, but also important for recreation and leisure for urban residents. For this reason, we should consider the possibility of creating entirely new types of urban design systems.

\subsection{Objectives and Novelity of the Reseach}

The objective of this paper is to identify the theoretical pattern of design principles including vertical farming in urban areas. The research hypothesis is to assume that green in vertical systems can be a strategically planned network of multi-functional and multiscale green areas, designed and managed in a way that aims to provide a wide range of ecosystem and social services. The authors of the paper believe that urban vertical farming can improve connectivity between existing urban green areas, counteract fragmentation, and enhance ecological coherence. The research analysis in this paper is intended to show whether it is possible to introduce various functions, supporting ecosystem and social services in a large-scale system of solutions in the field of vertical urban agriculture, and whether they affect measurable benefits for urban residents.

\section{Methods of the Research}

This paper examines the factors that, according to the authors, are directly and indirectly related to the quality of life in the city, i.e., economic and climatic/environmental support for ecological corridors, adapting to climate change, social factors, landscape, counteracting food shortage, tourism/recreation, spatial planning, counteracting social exclusion, and exchange in goods in the peer-to-peer model. These factors have been analysed in relation to the opportunity of applying three agro-urban models: an intensive model-with an organisation of urban vertical farms in high-quality buildings and on a city scale; an extensive model—takes into account construction of farms on wasteland and degraded areas on the scale of city districts (medium scale); and a dispersed model at the local scale-based on existing buildings and infrastructures (e.g., roof gardens, green facades). Plants on building structures undoubtedly have a positive effect on the aesthetics of the building, but also improperly designed systems on which they are placed may become the source of the building's destruction. Therefore, this paper also discusses construction aspects, especially the construction of green roofs and walls. Source material analysis, including case studies description and comparative analysis of urban vertical farming was used as the main research method. The conducted research is causal and concerns a newly investigated phenomenon-vertical urban agriculture. The research method was connected with case study analysis and included collecting and systematising data related to vertical urban agriculture, both empirical and theoretical, their organisation, systematisation, and evaluation.

\section{Addressing Societal Challenges by Vertical Greening}

An easily accessible green space creates a spectrum of possibilities to do sport, increases children's creative play, and improve social relationships between people of different religions and genders. Green space can encourage social interaction and can contribute to making higher density housing more attractive and safe. Widely accessible green spaces favour human interactions and, in this way, help in decreasing social exclusion and strengthening the link between urban and rural communities. The urban vertical 
greenery provides new opportunities for educational use of the area, and ensures that the mosaic of habitats in the forest can be used for the full range of environmental education needs of the surrounding schools. High-quality, nearby green spaces will encourage higher levels of physical activity, reduce travel distances, improve people's quality of life, provide opportunities for learning, and encourage expenditure in the local economy. They may also make areas more attractive to inward investment and agriculture. Building the urban vertical system will allow reparation of the ecosystem's integrity and enhance sustainable use of natural resources and biodiversity in the urban environment, which results in better provision of food, goods, and services to support human well-being.

One of the biggest challenges of modern agriculture is to provide access to food products for a population whose number in 2050 is to exceed 9 billion. It is estimated that global land management has already exceeded $80 \%$ of the available resources. The theoretical studies undertaken in the project may be a starting point for subsequent applied research and, as a result, contribute to the emergence of one of the important spatial planning tools. In a world where it is increasingly difficult to find a free fragment of space, the use of every fragment of the earth in a sustainable way plays a significant role. Vertical farming is less time-consuming and much more efficient than traditional farming, and thanks to a controlled environment, it allows you to combine crops within one structure that could not function side by side in natural conditions [4-11].

\section{Vertical Farming: From Antiquity to Modern Skyscrapers}

Introducing greenery to buildings has existed since antiquity. In Mesopotamia, more than 2500 years ago, the Hanging Gardens of Babylon were built on four terraces supported by a special structure consisting of narrow corridors. All levels were equipped with artificial irrigation with bituminous insulation and a layer of earth where shrubs and trees were planted. Since the description of the Hanging Gardens of Babylon, built by King Nebuchadnezzar II in about 600 BC, appeared in A Handbook to the Seven Wonders of the World by Philo of Byzantium, human history knew little evidence of the existence of vertical farming until the twentieth century. Among them worth noting is the innovative form of hydroponic farming created on floating rafts (chinampas) made of reeds, stalks, and roots introduced by the Aztecs around 1150 AD. Between the 3rd century BC, the Romans grew vines so that they would climb over the bars and the walls of houses [12,13]. Attaching plants to a fixed structure makes it easier for them to grow and lowers the stresses that the plant has to deal without a supporting structure. This solution was perfect for gardens with a small area. Over time, the practical palmetto has assumed an aesthetic function. The palmetto was used in the romanticism era, and climbing plants were used to age buildings. In the seventeenth century, the hydroponic method of plant cultivation was scientifically documented in books, such as Sylva Sylvarum written by Sir Francis Bacon; however, for the first time, the term of "vertical farming" was coined in 1915, when the American geologist, Gilbert Ellis Bailey, used the concept in his book, Vertical Farming, to describe multi-story buildings which are dedicated to indoor plant cultivation [14]. Construction of modern multi-story vertical farming, however, had to wait until 1992, when the first bioclimatic skyscraper, Menara Mesiniaga, was built in the densely populated capital of Malaysia [15]. The open cylindrical form supported on eight pillars incorporates into the design of various passive solar and natural ventilation techniques. Awarded in 1995, the building received an Aga Khan Award for Architecture and set established standards of design for contemporary green buildings in the world. In 1995, an arrangement similar to the Babylonian gardens was created in Japan. Emilio Ambasz designed the 15-story ACROS International Cultural and Information Centre, located in the city of Fukuoka. The walls are covered with greenery from walking terraces, which have been a natural extension of the park. Ambasz made the world interested in green architecture and unconventional solutions by introducing greenery in highly urbanized areas. The modern concept of vertical farms was developed by Dickson Despommier, a professor at Columbia University in New York in 1999 who proposed cultivating multi-story crops inside buildings. His project is a proposal of a 
thirty-story, artificially lit building, which, according to Despommier's calculations, could feed as many as 50,000 people [6,7]. Under his influence, the first practical implementations of vertical crops under a roof appeared.

In the twenty-first century, the idea of vertical farming grew from the single bioskyscrapers to the massive vertical food production buildings for commercial purposes, supported by the newest technologies which makes rapid growth and planned production possible where heat and lighting are provided by renewable sources of energy. Contemporary vertical plantations may resemble tall office greenhouses; however, more often, they take the form of indoor cultivation, where air, light, irrigation, substrate, and nutrients are supplied to the plants and monitored by a computer-controlled system. The seedlings are grown on special shelves, which allows for an optimally high food production in a relatively small area.

\section{The Impact of Vertical Greenery on Life in Cities}

The benefits obtained by using vertical gardens depend on the design factors, the vegetation used, the local conditions, and the scale of the project. In the urban landscape, both in the urban and architecture scales, this impact may help to:

- $\quad$ reduce the urban heat island effect through improving natural cooling processes and reducing ambient temperature and surface shading;

- $\quad$ help to restore the natural water balance in urban areas [16,17];

- $\quad$ improve the quality of outdoor air by capturing pollutants by filtering the air, depositing dust on the surface of leaves;

- $\quad$ improve aesthetics by creating panoramas and city views, obscuring unsightly surfaces, increasing property prices, and providing interesting free-standing structures;

- $\quad$ improve the energy efficiency of buildings by limiting heat loss and air conditioning cost through a thick layer of vegetation and creating a buffer zone against the wind;

- $\quad$ protect the building structure against UV radiation and temperature fluctuations by increasing the tightness of openings in partitions;

- improve indoor air quality with the absorption of dust, pollen, and harmful gases;

- $\quad$ reduce noise by absorbing and reflecting sound waves [18];

- multiply harvests in urban areas and improve the quality of agricultural products provided to urban residents;

- $\quad$ reduce food production costs due to better provision of food to local/district markets;

- $\quad$ and provide greater accessibility to recreational areas.

The positive impact of urban agriculture on the environment manifests itself in reducing heat, named as the urban heat island (UHI) effect, by reducing the activity of greenhouse gases, creating the possibility of revitalising urban wastelands, and preventing the loss of rainwater. There are undoubtedly significant social benefits resulting from urban agriculture, manifested in increasing social participation, building a strong local community that cares about its surroundings, and creates a new urban and human-friendly space in environmental education [19]. Urban agriculture, on the other hand, stimulates physical activity of the inhabitants and facilitates the consumption of fruit and vegetables, thus contributing directly to improving the quality of life and health of society.

It is worth paying attention to the possibility of the versatile use of post-industrial facilities for urban agriculture as one of the methods of their revitalisation. This form of supplying people living in the agglomeration with organically grown vegetables may also contribute to the independence of cities in terms of access to food produced locally. In heavily polluted areas of industrial and post-industrial cities, vertical crops can be grown and harvested in a clean environment, without contact with external pollutants and without the use of plant protection products. Despite multiple benefits from urban vertical farming, some difficulties are encountered in reality for the installation of green solutions, e.g., building constraints, as installation and management costs should be taken into account before planning, designing, and building vertical farms in contemporary cities. 


\section{Vertical Farming Techniques}

The father of vertical gardens is Patrick Blanc, a French scientist and botanist. Patrick Blanc in 1988 patented a solution to design plants without soil in an upright position. The technology is based on a felt fabric that replaces soil, which absorbs and retains water. The felt layer is attached to a PVC board with a special mesh with elements supporting the plant structure. Plants grow into the felt layer over time. The entire complex is equipped with an irrigation system, from which the water is discharged into the sewage system or for reuse. Establishing vertical gardens requires taking into account natural aspects (such as precipitation, wind, snow cover, and insolation) and construction aspects (e.g., wall resistance to additional loads). The difference in climatic conditions, location, and available construction materials influenced the creation of various systems that allow the establishment of gardens of different heights and shapes [20].

- The different techniques used in vertical farming include:

- Hydroponics-the roots of the plants are submerged in a mixture of nutrients. Hydroponic plantation demands help to maintain the chemical composition of nutrients [21,22];

- Aeroponics-the technique invented by NASA in the 1990s of growing plants with no soil and a small amount of water absorbed by plant roots from the mist with a nutrient solution;

- Aquaponics - an ecosystem based on the symbiotic relationships between fish and plants. The explanation for aquaponic farming was the vision of implementation of semi-self-sufficient system in which fish in the pond can produce nutrient-rich waste that further helps plants to grown in a vertical farm [23-25];

- AeroFarms-innovation of using the aeroponic system of farming, which is based on the use of smart technologies (e.g., smart light, smart nutrition, and smart pest control);

- Modular Farms - an entirely indoor system of vertical farming, based on containers with an ability to produce plants in any climate and anywhere in the world. A variation of this system is Cubic Farming systems based on an automated nutrient delivery system and LED lighting.

\subsection{Green Roofs}

In the city centres, due to the price of plots, high urban development density, and the existence of historical buildings, vertical crops can be cultivated frequently only on roofs or on the green façade system. Green roof plantations are a type of cultivation which are especially recommended for growing plants that require intense sunlight and are resistant to fluctuations in temperature and humidity $[9,26]$. The production of plants on the roof can be divided into three categories, depending on the intensity of production: rooftop gardening (usually on a small scale), rooftop farming, and rooftop agriculture (taking the most intensive form) [27]. Green roofs provide roof protection against direct ultraviolet rays and reduce the heating of the partition in hot weather. Heat flux through a green roof is dependent on the weather, with less heat gain and more heat loss on sunny days, but a notable decline in both attributes on cloudy days. On rainy days, green roofs assume an energy conservation role with a slight increase the cooling load, as opposed to a reduction [28]. Green roofs lower the temperature in the building by about $3.4^{\circ} \mathrm{C}$ [29]. In buildings without air conditioning, the temperature on the top floors can be about $2{ }^{\circ} \mathrm{C}$ lower than in buildings with traditional roofs [30-32]. By cooling roofs, designers can reduce the amount of absorbed solar energy, and thus reduce heat conduction to buildings. It has been shown that, in flats located on top floors, under green roofs, the demand for cooling energy decreases from $10 \%$ to $40 \%$ (depending on climatic conditions and building construction) [33-35]. The results of research conducted in Toronto show that savings from cool roofs can be about $20 \%$ [36]. In the winter, heat loss from inside the building through the green roof is much lower than in buildings with a traditional roof construction. This reduces the demand for heat energy on the top floors. For both cooling and heating the 
building, reducing energy demand due to the green roof means reducing $\mathrm{CO}_{2}$ emissions from energy or heat generation [31,32,35].

Green roofs can absorb rainwater directly, but require the use of special membranes to protect plant roots and the energy needed to irrigate in dry seasons. The placement of roof gardens poses a number of challenges for designers and contractors. When designing a green roof, the following factors should be taken into account.

- Accurate consideration of the weight of all system layers, the substrate in a state of maximum soaking, the weight of plants, small architecture, and precipitation.

- The design of an appropriate roof slope. The slope of green roofs is usually in the range from $0^{\circ}$ to about $30^{\circ}$. There are also possible inclinations, even $90^{\circ}$ (cylindrical roofs). However, with a roof slope of less than $2 \%$, attention should be paid to waterproofing. Therefore, on roofs without slopes, tested waterproofing materials with correspondingly greater thickness or more layers should be used. Waterlogging on the substrate surface during prolonged rainfall can cause the plants to rot.

- The protection against slipping on the pitched roof. The pitched roof requires the application of special protection to prevent the green roof layers from sliding.

- The use of waterproofing with root overgrowth resistance (membranes). Damage to the waterproofing by overgrown roots can lead to flooding.

- The use of an appropriate drainage system ensures a sufficient number of inlets and their favorable distribution, application of gravel bands, and drainage mats.

- The use of substrate instead of fertile soil. Small fractions flushed out by rainwater can clog up rainwater drainage and flood the building.

A large number of roof devices are located on roofs: air handling units, antennas, lightning protection systems, or ventilation chimneys. In total, there are a dozen to several dozen places where the roof covering has to be broken. Each of these points should be insulated with the utmost care.

\subsection{Vertical Green Systems}

Green façades are another interesting solution in the field of green architecture that improve the thermal insulation of buildings, which can be used in city centres. The system is based on a flexible modular structure attached to the whole façade or implemented as a part of an existing structure. Among the several benefits of such a form of vertical farming are soundproofing, supporting a healthy work environment, improving the microclimate, thermal insulation, and delivering shade [37]. Vertical greening systems (VGS) are known as green-wall technologies, vertical gardens, or bio walls. They consist of vertical structures that spread vegetation that may or may not be attached to a building facade or to an interior wall [38]. There are three basic systems used to create green walls: a panel system (modular), a felt pocket system (hydroponic), and a container system [39].

The modular panel system is based on a system of panels made of plastic, stainless steel, aluminium, and recycled materials. These panels are easy to assemble, fixed from independent parts, which makes them easy to remove if necessary. The purpose of these modules is to support the roots and provide them with nutrients. Most solutions replace the soil with perlite, expanded clay, mineral wool, coconut fibre mat, peat moss, etc. [40]. The felt pocket system is the simplest system in terms of assembly. It consists of a frame as the structure, an insulating layer (usually a PVC board) that insulates the wall from wet felt and mats made of synthetic fibres (mainly felt). A waterproof backing is required to isolate the living wall from the building in order to avoid problems associated with dampness. Felt mats consist of pockets where plants are placed. The porous structure of the felt helps the plants to take root and provide air and water [40]. The felt pockets systems are not recommended for large spaces and very tall buildings. In the case of large surfaces, the strength limits of the felt and the weight of the soil must be taken into account. Based on this idea, new solutions are created, which mainly concern the materials from which pockets are made. 
The container system consists in creating a spatial truss structure divided into many levels, on which containers with plants are placed. The containers are filled with a suitable medium capable of storing water and nutrients. Plants climb on steel ropes or nets, which can be used to create simple or more complex forms. Many materials can be used as support for climbing plants, such as steel (coated steel, stainless steel, galvanised steel), different types of wood, plastic, or aluminium. This solution is more spacious and takes up more space than pocket and panel systems. The arrangement of ropes can be freely designed $[39,40]$.

The durability of living walls varies according to the type of system available. Living walls with panels based on felt layers have an average life expectancy of 10 years, and living walls based on planter boxes last more than 50 years. A thorough design (especially details of window ledges, doors, etc.) is required to avoid damage, such as corrosion or rot, caused by leakage of water and nutrients [41]. The green layer also results in a shading effect, which reduces the amount of UV light that will fall on building materials since UV light deteriorates the material and mechanical properties of coatings, paints, plastics, etc. [41]. Measurements performed by Bartfelder and Köhler [42] show a temperature reduction at the green façade in a range of $2{ }^{\circ} \mathrm{C}$ compared with a bare wall. The study conducted by Wong et al. in Singapore [43] on a free standing wall in Hortpark (Singapore) with vertical greening types shows a maximum reduction of $11.6{ }^{\circ} \mathrm{C}$.

The humidity measurements on a bare façade and on a green one show that, with a green layer, the façade is drier during summer [42]. Green walls systems protect from rain and moisture, thanks to the continuous layer constituted by the greened modular panels. Hazards related to the use of plants, especially climbing plants mainly are in regard to damage on the building envelope caused by the choice of strong species with plants with thick branches, as well as supporting structure deformations caused by an inappropriate estimation of the green weight. These possible problems are connected to the disposal of excess water from the building envelope. Failure to drain water from the façade may damage windows and doors.

\section{The Role of Vertical Greenery in Nature-Based Solutions in Cities}

Cities have the capacity to create environmentally valuable new green areas; the detailed identification and assessment of their introduction is one of the basic rationale for a sustainable spatial economy. New green areas in cities are a source of health benefits, such as clean air, better water quality, greater accessibility to recreational areas, and access to the city's fruit and vegetables. Green areas deliver a range of interdependent benefits (environmental, economic, and social) such as reducing storm water runoff volumes, enhancing groundwater recharge, improving environmental quality, reducing sewer overflow events, mitigating the urban heat island effect, increasing biodiversity, improving human health and well-being, and increasing land values in surrounding residential areas. Vertical greenery improves connectivity between existing urban green areas counteracts fragmentation and enhances ecological coherence. Newly created vertical urban farms will, in the future, not only increase harvest yields or reduce production costs, but also significantly improve the quality of agricultural products provided to urban residents, and thus minimise the adverse impact of urbanisation on the environment $[5,44]$. Researchers have suggested that the aquaponics system has the potential to become a model of sustainable food production by achieving the $3 R$ s, i.e., via a means to reduce, reuse, and recycle $[23,24]$. This system, resulting in a polyculture that increases biodiversity, can support cities ecosystem services in the future, helping in cleaning water, providing organic liquid fertilisers, and reducing waste from organic products. Aquaponic farming is close to achieving a closed-loop agricultural ecosystem intended to mimic natural ecosystems. In the future, such a system can recycle and reuse every element of the farming process. Research indicates that an anaerobic digester, for example, which is a biogas recovery system, can convert food waste into biogas to produce power and heat $[37,45]$. Great Northern Hydroponics (GNH) in Quebec, Canada has implemented several technological innovations to mimic the natural 
ecosystem, such as an anaerobic digester that turns organic materials into biogas piped into a turbine generator to make electricity for farms, commercial kitchens, and a Kombucha tea brewery; produce oxygen to the tea brewery, which creates $\mathrm{CO}_{2}$ to the plant; and recycle organic waste from inside the vertical farm and from the tea brewery [37]. The closed-loop agricultural ecosystem of the Great Northern Hydroponics produces tea, fresh vegetables, fish, beer, and food, operating on an almost-self-sufficient zero-energy and zero-waste system.

A number of benefits for the natural environment of vertical urban farms, in addition to the general benefits of existence of green areas in the urban environment, also include:

- independence of vertical crops from the polluted external environment of cities;

- the possibility of using ecological "green technologies", allowing for lower energy consumption;

- $\quad$ energy savings and the possibility of using energy from renewable sources [46,47];

- $\quad$ achieving the postulate of sustainable development for the benefit of the environment;

- low water consumption, which contributes to better sustainable water management;

- the possibility of using the organic waste generated in the vertical farm, which can be composted on site;

- $\quad$ reducing the excessive use of pesticides and herbicides;

- $\quad$ and reducing carbon dioxide emissions to the environment [7].

\section{Multi-Scale Aspects of Vertical Farming: Case Studies}

The basic assumption of agro-urbanism is to create places for growing plants in the urban space organised in three ways: intensive-establishing the organisation of vertical farms in high-rise buildings using the latest agricultural and construction technologies, e.g., Sky Greens in Singapore; extensive-taking into account the construction of farms with a height not exceeding the surrounding buildings in undeveloped or degraded areas; and dispersed-based on existing buildings and infrastructure, whose elements can be used for agricultural purposes without the need for advanced and expensive technologies [48-50]. Analysis of the implementation of agro-urbanism and agro-architecture in three dimensions (intensive, extensive, and dispersed) took into account the multi-scale of vertical farming. The analysis included in the chapter confirm the possibility of vertical farms functioning at various scales (city/district, neighbourhood, and local area), depending on the needs and financial possibilities of the cities.

\subsection{City Scale Vertical Farming: Maxi Dimension}

Currently, vertical farming in cities is implemented in two types of developments. The first is adapted in post-industrial buildings and warehouses, and the second is investments implemented from the beginning with specific design principles. Planned buildings are designed structurally and technologically in a way that allows the cultivation of plants and the purpose of using the building is already assumed. The design challenge here is not only combining engineering and environmental protection requirements with economic and utility functions of buildings, but also implementing such a design that takes into account the requirements of aesthetics and broadly understood spatial order issues. In contemporary cities, the supply of fresh fruit and vegetables covers the entire logistic chain, including transport, storage, and packaging. Each of these stages produces pollutants that affect waste production and the overall health of the population. Some cities take up the challenges posed by a future related to the growing number of residents and the need to provide sufficient supplies of food for a fast-growing population. Examples of such solutions covering significant parts of the city in terms of surface area are being developed all over the world, such as the Forest City (Malaysia), the Sunqiao (China), or Chaise Urbaine (Strasbourg, Europe). In Strasbourg, vertical gardens are used to cover the entire post-industrial district located on $31,000 \mathrm{~m}^{2}$. As a result, a modern multi-functional space, including houses, services, and offices, is to be created in the near future. On the terraces of the apartments, lush, watered gardens will be created thanks to the use of an integrated rainwater system. 
In Forest City, Malaysia, with a surface area of almost four times the size of Central Park in New York, four artificial islands are being built in Singapore as a partnership between the Chinese developer Country Garden and Esplanade Danga (99.9\% of which is owned by the Sultan of Johor). With 700,000 inhabitants, it will be the most densely populated human settlement on Earth. According to the vision plan, major buildings will be covered in plants. The high density of the new city will be reached thanks to tall buildings: residential high-rise concrete towers, office towers, shopping malls, and hotels. The benefits associated with the creation of a new economic engine in the Malaysian city can be outweighed by the negative ecological impact of the investment environment. A total of $162,000,000 \mathrm{~m}^{3}$ of shipped-in sand used in construction can cause irreversible disruption of the surrounding entire maritime environment [51,52].

In Sunqiao (China), a new housing district, whose construction began in 2017, represents an example of urban agriculture in where vegetables can grow vertically, in the form of skyscrapers. According to initial estimations, over half (56\%) of the diet of Shanghai's inhabitants is based on leaf vegetables, which do not require specific care and can grow in hydroponic and aquaponic systems. The district visualisation shows lavish, flourishing gardens growing on floating greenhouses, green walls, and vertical façades. The vegetables, fruit, and herbs in the vertical farming system in Sunqiao can support the local food network and control the local production and distribution of food within the city. The new housing district covers an area of 100 ha and is located between Shanghai's main airport and the city centre [53-57].

\subsection{Neighbourhood Vertical Farming: Combined Structures of Vertical Farms (Midi Dimension)}

The world's first large-scale vertical farm began commercial operations in 2012 in Singapore under the name Sky Greens. Production follows the 3R principle (reduce, reuse, and recycle) thanks to the reuse of waste generated in the production process. Subsequent municipal farms using available technologies use full automation to create a completely controlled environment, with an ultra-modern lighting system ensuring high yields and high-quality products with the lowest possible negative impact on the environment. Vertical farms are being built all over the world with different cultivation ideas and business models. One of the largest is AeroFarm, located in an abandoned hall in New Jersey. Aero Farms (USA), with a total area of nearly $10,000 \mathrm{~m}^{2}$, has started commercial operations in the USA. Using a patented aeroponic cultivation system, in a completely controlled atmosphere, with an ultra-modern lighting system, the farms have been designed in such a way as to shorten the cultivation cycle as much as possible, ensuring high-quality products with the least adverse environmental impact. There are 250 types of leafy green vegetables, such as arugula, kale, and spinach, placed on special shelves over $6 \mathrm{~m}$ high. The photosynthesis process takes place thanks to LED lights (the intensity, length, and spectrum of which are tailored to the individual needs of each species). Produced in this way, fresh vegetables are sold to local corporations, restaurants, supermarkets, and schools [58]. Sky Greens (Singapore) is hydraulic-driven vertical farming in which vegetables are planted on shelves rotating from the bottom to the top throughout the day to deliver sunlight and water for growing plants. It is estimated that each of the nine-metre towers that form the basis of the farm's operation yields can produce five to ten times more vegetables than would be possible with conventional farming methods on the same acreage. The Sky Greens farm uses little energy. The farm is also focused on low water consumption. For irrigation of plants, rainwater collected in a special tank is used, and the water used up in cultivation is recycled and reused. Sky Greens uses sustainable resource management systems and recycling technologies (https://www.skygreens.com/ (accessed on 15 June 2021). The building emits traces of carbon dioxide and pollutants [59].

\subsection{Neighbourhood Vertical Farming: Single Structures of Vertical Farms (Midi Dimension)}

The 16-story tower of the Plantagon World Food Building in Linköping, Sweden is designed as a vertical agriculture urban farm in urban areas with integrated solutions for 
energy, excess heat, waste, $\mathrm{CO}_{2}$, and water recycling. It is planned that the waste from the greenhouse is then sent to the biogas plant located in the neighbourhood for composting, which will finally deliver energy that enables the plantation to operate. The World Food Building is predicted to produce approximately 550 tons of vegetables, save 1100 tons of $\mathrm{CO}_{2}$ emissions and 13,000,000 gallons of water annually, which, according to estimates, will feed around 5500 people each year (http:/ / www.verticalfarms.com.au/advantagesvertical-farming, accessed on 15 June 2021). Two-thirds of the building will be allocated to offices, local restaurants, and a market for selling vegetables and fruit, and the other third will include an indoor farm [60].

An interesting option for highly congested cities could be the vision of Chetwood Architects, who proposed turning London Bridge into an urban vertical farm to support the local organic market with solar-powered spires topped with wind turbines. In the concept, organic farms will be placed on vast platforms which incorporate solar water heating, rainwater collection, and grey water treatment.

\subsection{Local Vertical Farms: Micro Dimension}

Vertical farms on a local scale include a variety of solutions in the field of green architecture: green roofs on individual buildings, green façades, and many other micro-solutions. Miniature farms equipped with the latest technologies are available to every investor, anywhere on Earth. In the dimension of a single household, they include the cultivation of plants in a multi-story system on balconies, terraces, roofs, or in corridors of buildings using sunlight or creating modular farms completely isolated from the environment or a Cubic Farming system. An example of such a solution is the Leafy Green Machine-a vertical farm the size of a TIR semi-trailer, fully isolated from the outside world.

One of the examples of the location of an investment on a micro-and midi scale in the form of a single green roof is a commercial hydroponic vertical farm in New York, known as Gotham Greens. Gotham Greens, a commercial hydroponic urban farm constructed in 2011, supports residents of New York and Chicago with fruit and vegetables planted on a rooftop farm without using pesticides. Gotham Greens is a $1394 \mathrm{~m}^{2}$ facility located on a roof of the two-story building in Greenpoint, Brooklyn. Gotham Greens depends on an irrigation system, which is based on reusing water and contributes to the city recycling system based on a concept of a closed-loop ecosystem with recycling, reusing, remanufacturing and composting (http://gothamgreens.com/, accessed date: 10 August 2021). The newest urban farms use smart technologies to control the supply of water and fertilisers needed for growing crops. The hydroponic Gotham Greens commercial farm uses technologically advanced controlled environment agriculture (CEA) in order to make the crops independent of the influence of the external environment and deliver vegetables to the local market all year round [61,62]. The Dakakker (Rotterdam) is related to a location on the smart roof of the botanical garden with aromatic herbs and six beehives. Thanks to such a micro-solution, local biodiversity can be increased, supporting the lives of various insect species.

\subsection{Vertical Farming in Polish Cities}

The history of vertical agriculture is short; however, among the few examples of such constructions, we can find the unique idea and implementation of the Ruthner Tower, a vegetable and gardening tower, erected in the Provincial Park of Culture and Recreation in Chorzów, Poland. The construction of this was licenced by the Viennese company Ruthner Industrieanlagen fur Pflanzenbau G.m.b.H. Until recently, it was the first and only example of vertical cultivation in Poland. It was erected in the Provincial Park of Culture and Recreation in Chorzów solely for the purpose of vertical crops. The greenhouse was to be a prototype facility for the production of vegetables and flowers. The vertical greenhouse complex consisted of the main greenhouse building and the main one-story facility, housing the laboratory, wardrobe, as well as sanitary and utility rooms [63]. The tower has is of a cylindrical shape, with a diameter of $11 \mathrm{~m}$ and a height of $54 \mathrm{~m}$, and includes $1200 \mathrm{~m}^{2}$ 
of cultivation area. It was presented on 23 June 1968, during the Polish Horticultural Exhibition ceremonial opening. The author of the project was a Viennese engineer and pioneer of vertical agriculture called Othmar Ruthner. All the technology and most of the materials needed for the construction of the project were ordered and purchased in Austria. Interestingly, the innovative investment of Othmar Ruthner's vegetable and horticultural tower is located in Upper Silesia, which is the heavily industrialised heart of the country and part of the Metropolis of Upper Silesia and Zagłębie. The production line system for a fresh fruit and vegetable factory, combining hydroponic technology for soilless cultivation with fully automated production line technology, was developed and patented by Othmar Ruthner [63]. After the Second World War, similar experimental hydroponic towers were built by Ruthner in Berlin, Oberlaa Park in Vienna, and Grossenzersdorf near Vienna, and a small tower in Iran producing peppers and tomatoes. The decision to locate one of the towers in Chorzów was directly influenced by the Vienna International Horticultural Exhibition (Wiener Internationale Gartenschau (WIG)) in 1964. In the 1960s, there was a lot of interest in food supply towers in the world, independent of climatic factors and producing healthy vegetables. There are many such investments in various places around the world, including Austria, Germany, Sweden, Italy, Norway, Russia, Canada, Libya, Iran, Japan, and Poland. The largest of these towers has been unexpectedly built in the Libyan desert and produced 10 tons of cattle feed, which allowed 350 cows to be fed. It should be mentioned that a significant number of these towers were dismantled in the 1980s. The tower in Austria located in Wiener Neustadt operated for the longest time (from 1965 to 2006). The tower in Chorzów was dismantled in the mid-1980s. The reasons for this were erosion of panels as a result of high humidity inside the greenhouse, and internal stresses in panels resulting from strong wind pressure [63].

Nowadays, vertical plant cultivation is being introduced on a small experimental scale by the Carrefour chain of stores, which, in Poland, in cooperation with the start-up Listny Cud, has installed two small vertical farms in its large-area stores. As a result, customers were given access to fresh microlists of red cabbage, broccoli, radish, mustard, and arugula. The offer for the individual market concerns the following microfarms: hydroponic (www.green-farm.pl, accessed date: 10 August 2021) and aeroponic (www. aerotower.pl; accessed date: 10 August 2021). One of the first crops was established on a larger scale in Kraków. Urbanika Farms (www.urbanikafarms.com; accessed date: 10 August 2021) has established its experimental farm in the premises of the Faculty of Biotechnology and Horticulture at the University of Agriculture, and, with the substantive support of Kraków scientists, it aims to deliver fresh products to local supermarkets and restaurants.

The future for Polish cities, in terms of the possibilities of greening cities and incorporating vertical gardens in urban areas, is now more optimistic. In Poland, 44 towns and cities have prepared urban plans for adaptation to climate change as part of the project Opracowanie planów adaptacji do zmian klimatu w miastach powyżej 100 tys. mieszkańców (Development of Urban Adaptation Plans in Poland for cities with more than 100,000 inhabitants) [64]. Among the number of nature-based solutionsm there are ideas for the development of vertical agriculture. The purpose of the adaptation plans is to increase the resilience of cities to climatic phenomena, taking into account constantly changing climatic conditions. In Łódź, adaptation measures, in addition to many other aspects, concern the introduction of blue and green infrastructure elements, and the protection of urban ventilation corridors. In Kraków, the adaptation plan includes increasing greenery in the city (forests, large urban parks, river parks, pocket parks, street trees, urban vertical greenery, and green roofs). The Environmental Development Commission (Komisja Kształtowania Środowiska) has decided to submit a request to the mayor of Kraków regarding the creation of a pilot support programme for the development of green roofs and vertical gardens. As part of its green infrastructure project, 24 pocket parks have been created in the city in recent years. The new pocket parks, also known among the city's residents as the "Gardens of the Inhabitants of Kraków", were implemented by Zarząd Zieleni Miejskiej 
(ZZM). Ultimately, 70 pocket parks with an area of up to $5000 \mathrm{~m}^{2}$ are to be created in the near future $[65,66]$.

Vertical agriculture is slowly but steadily developing in Poland, accompanying other goals related to improve the bioclimate of cities and mitigating the effect of urban heat leakage. Start-ups are being established increasingly often which, while looking for profitability of investments in vertical agriculture, follow the latest available technologies, in which smart solutions and the Internet of Things have a growing influence.

\section{Research}

The tendency to create vertical farms in various systems and scales is visible in each of the climatic zones. Independence from climatic conditions and lower demand for water mean that vertical farms, regardless of their location, can offer exactly the same functions, and residents can enjoy similar benefits. Figures 1-4 show factors that, according to the authors, are directly and indirectly related to the quality of life in the city, i.e., both economic and climatic/environmental, which support ecological corridors; adapt to climate change, social factors, and landscape; and counteract food shortages, tourism/recreation, spatial planning, social exclusion, and, finally, the exchange in goods in the peer-to-peer model. The factors shown in Figures 1-4 were selected on the basis of the analysis of the case studies. Vertical farms in the urban fabric can not only perform many functions, but also bring many benefits to the inhabitants of cities, housing estates, and houses. These include economic, social, environmental, and planning benefits (Figures 1-4).

Thanks to vertical farms, the urban fabric gains create additional usable spaces. In a multi-scale system, this allows for the creation of patchwork connections, which, through the strength of their connections, stabilise a specific city biome in the vertical space. The essence of the multi-scale vertical farms in the urban fabric is a way of creating from stage 1 (the initiation stage), based on individual initiatives of residents to green their immediate surroundings (balcony, terrace, building) to other stages (2-5), connecting green areas at the large-space level (Figure 5).

\begin{tabular}{|c|c|c|}
\hline MACRO SCALE & MEDIUM SCALE & MICRO SCALE \\
\hline $\begin{array}{l}\checkmark \text { vertical cultivation makes it possible to make better use of space } \\
\text { in cities and create a new quality of urban fabric, } \\
\checkmark \text { vertical farms are characterised by high productivity of vertical } \\
\text { crops thanks to denser sowing and faster plant growth and } \\
\text { development, } \\
\checkmark \text { no need to transport food due to its direct location, } \\
\checkmark \text { the ability to easily and quickly adapt the type of production to } \\
\text { the current needs of city residents, } \\
\checkmark \text { an increase in property prices in new eco-cities, which translates } \\
\text { into an increase in the economic base of cities, } \\
\checkmark \text { greater independence of cities in access to food directed at the } \\
\text { local market and the possibility of selling local products to the } \\
\text { external market. } \\
\text { COUNTERACTING FOOD LOSS }\end{array}$ & $\begin{array}{l}\checkmark \text { adaptation of post-industrial buildings to vertical farms allows } \\
\text { these facilities to generate income from urban agriculture, } \\
\checkmark \text { better automation based on a rotation system adapted to easy } \\
\text { harvesting, } \\
\checkmark \text { plants grow in a controlled, climate-independent environment, } \\
\text { which allows them to produce more crops, } \\
\checkmark \text { multi-storey farm buildings give the possibility of harvesting } \\
\text { crops all year round, } \\
\checkmark \text { vertical farms represent a medium investment risk due to their } \\
\text { increased popularity among city dwellers in the post-COVID } \\
\text { cra, } \\
\checkmark \text { possibility of using urban wastelands for vertical farms - e.g. } \\
\text { post-industrial areas. } \\
\text { COUNTERACTING FOOD LOSS }\end{array}$ & $\begin{array}{l}\checkmark \text { modular plant or vegetable cultivation is easy both to assemble } \\
\text { and to dismantle, which results in its low cost, } \\
\checkmark \text { low investment risk, } \\
\checkmark \text { possibility of alternative development in city centres, } \\
\checkmark \text { green façades and green roofs improve the energy properties of } \\
\text { buildings, thus reducing heating and air conditioning costs. } \\
\text { COUNTERACTING FOOD LOSS } \\
\checkmark \text { the possibility of creating local vertical farms based on existing } \\
\text { buildings (green walls, green roofs, green architecture), } \\
\checkmark \text { the possibility of using almost any space of the building for the } \\
\text { cultivation of plants - vegetables, fruit, herbs (e.g. terraces, roofs, } \\
\text { balconies, corridors in buildings). }\end{array}$ \\
\hline $\begin{array}{l}\checkmark \text { an alternative to traditional agricultural land use }(80 \% \text { of the } \\
\text { world's arable land is currently used, with the remaining } \\
20 \% \text { being wasteland) } \\
\checkmark \text { the possibility of implementing new solutions in the field of } \\
\text { bioarchitecture and agro-urban planning } \\
\checkmark \text { increasing the area of crops in the era of extensive land use }\end{array}$ & $\begin{array}{l}\checkmark \text { the possibility of introducing } 3 \text { agro-urban models: } \\
\text { - intensive - with the organisation of urban vertical farms on the } \\
\text {-ity scale, } \\
\text { - extended - including the construction of vertical farms in } \\
\text { - degraded areas, } \\
\text { dispersed - based on existing buildings and infrastructure (e.g. } \\
\text { green walls, green roofs) }\end{array}$ & $\begin{array}{l}\text { THE ECONOMY OF SHARING } \\
\checkmark \text { on the basis of new neighbourly spaces, the creation of places of } \\
\text { exchange of goods by residents }\end{array}$ \\
\hline THE ECONOMY OF SHARING & THE ECONOMY OF SHARING & \\
\hline $\begin{array}{l}\checkmark \text { vertical farms can significantly increase the self-sufficiency and } \\
\text { security of cities due to the food supply and serve metropolitan } \\
\text { centres by ensuring the exchange of goods and goods between } \\
\text { cities }\end{array}$ & $\begin{array}{l}\checkmark \text { creating places for the exchange of goods and products related } \\
\text { to vertical farms by residents of housing estates on a shared } \\
\text { economy basis }\end{array}$ & \\
\hline
\end{tabular}

Figure 1. Multi-scale economic benefits resulting from the existence of vertical farms in the urban fabric (own elaboration). 


\begin{tabular}{|c|c|c|}
\hline MACRO SCALE & MEDIUM SCALE & MICRO SCALE \\
\hline $\begin{array}{l}\checkmark \text { creating a new human-friendly space in the city supporting } \\
\text { environmental education, } \\
\checkmark \text { influence on shaping the new pro-social policy, } \\
\checkmark \text { improving the health and quality of life of urban residents } \\
\text { thanks to the higher quality of products offered by municipal } \\
\text { farms (elimination of pollution, artificial fertilizers and } \\
\text { pesticides). }\end{array}$ & $\begin{array}{l}\checkmark \text { the possibility of the wide use of services offered by multi- } \\
\text { functional city farms on the scale of a residential district (e.g. } \\
\text { catering services, recreational services), } \\
\checkmark \text { stimulating physical activity of residents by introducing sports } \\
\text { and recreation services, } \\
\checkmark \text { Based on the infrastructure of municipal farms, it is possible to } \\
\text { organise workshops for residents. }\end{array}$ & $\begin{array}{l}\checkmark \text { creating new, intimate neighbourhood spaces supporting small } \\
\text { social groups } \\
\checkmark \text { creating small gardens for the elderly and the disabled in the } \\
\text { immediate vicinity of their residence }\end{array}$ \\
\hline PARTICIPATION & PARTICIPATION & \multirow{3}{*}{$\begin{array}{l}\text { PARTICIPATION } \\
\checkmark \text { the possibility of creating places for social participation } \\
\text { supporting e.g. the harvesting of local crops, } \\
\checkmark \text { the possibility of organising workshops based on } \\
\text { multifunctional city farms, trainings courses involving the local } \\
\text { community. } \\
\text { CONTERACTING SOCIAL EXCLUSION }\end{array}$} \\
\hline \multirow{2}{*}{$\begin{array}{l}\checkmark \text { increasing social participation thanks to the creation of new, } \\
\text { green, residents-friendly urban spaces, } \\
\checkmark \text { the possibility of using the knowledge and preferences of society } \\
\text { to create new, multifunctional green public spaces. }\end{array}$} & \multirow{2}{*}{$\begin{array}{l}\checkmark \text { building a strong local community that cares about its } \\
\text { surroundings, } \\
\checkmark \text { creating a new, safe, healthy social space important in the post- } \\
\text { pandemic era. }\end{array}$} & \\
\hline & & \\
\hline CONTERACTING SOCIAL EXCLUSION & CONTERACTING SOCIAL EXCLUSION & \multirow{4}{*}{$\begin{array}{l}\checkmark \text { counteracting social exclusion by creating a new quality of } \\
\text { neighbourhood space. } \\
\text { TORISM AND RECREATION } \\
\checkmark \text { creating new, resident-friendly, intimate neighbourhood spaces, } \\
\checkmark \text { increasing the attractiveness of the area due to the aesthetics of } \\
\text { new green architecture. }\end{array}$} \\
\hline $\begin{array}{l}\checkmark \text { new quality of public spaces based on vertical farms is } \\
\text { conducive to building a strong community resistant to the } \\
\text { phenomenon of social exclusion. }\end{array}$ & $\begin{array}{l}\checkmark \text { participation in creating and managing a common space } \\
\text { contributes to building a stronger local community, regardless } \\
\text { of religion, gender and economic status. }\end{array}$ & \\
\hline TOURISM AND RECREATION & TOURISM AND RECREATION & \\
\hline $\begin{array}{l}\checkmark \text { supporting recreation in the city by creating new „green" urban } \\
\text { spaces, } \\
\checkmark \text { modern eco-cities with vertical farms are an important tourist } \\
\text { attraction in the sector of urban tourism, } \\
\checkmark \text { enriching and diversifying the recreational offer dedicated to } \\
\text { urban residents. }\end{array}$ & $\begin{array}{l}\checkmark \text { the possibility of developing business tourism based on } \\
\text { multifunctional centres of vertical farms (conference centres can } \\
\text { be created in new and adapted buildings), } \\
\checkmark \text { creating new, resident-friendly places at the estate level based } \\
\text { on ecological services (including catering, sports, social). }\end{array}$ & \\
\hline
\end{tabular}

Figure 2. Multi-scale social benefits resulting from the existence of vertical farms in the urban fabric (own elaboration).

\begin{tabular}{|c|c|c|}
\hline MACRO SCALE & MEDIUM SCALE & MICRO SCALE \\
\hline $\begin{array}{l}\checkmark \text { the possibility of using vegetation on a macro scale in ecosystem } \\
\text { services for the needs of the city (e.g. rainwater treatment), } \\
\checkmark \text { impact on the city's bioclimate by including the vertical green } \\
\text { system in the green infrastructure system, } \\
\checkmark \text { possibility of sustainable use without exploiting natural } \\
\text { ecosystems, } \\
\checkmark \text { the possibility of using energy from renewable sources, } \\
\checkmark \text { a positive impact on pollution in cities by reducing the need for } \\
\text { food transport, increasing the green area and biologically active } \\
\text { areas in the city, } \\
\checkmark \text { saving water needed for production in a closed environment, } \\
\checkmark \text { reducing the amount of rainwater runoff, improving } \\
\text { groundwater supply, } \\
\checkmark \text { sustainable food production by achieving the 3Rs (reduce, } \\
\text { reuse, and recycle) on a city scale, } \\
\checkmark \text { protection of natural and semi-natural areas in the vicinity of } \\
\text { the city against extensive agricultural use. }\end{array}$ & \multirow{3}{*}{$\begin{array}{l}\checkmark \text { elimination of negative factors (such as pollution, acid rain) in } \\
\text { the immediate vicinity of the apartments, } \\
\checkmark \text { impact on the microclimate of residential districts, } \\
\checkmark \text { the possibility of combining crops that could not function side } \\
\text { by side in natural conditions within a single structure, } \\
\checkmark \text { sustainable food production by achieving the 3Rs (reduce, } \\
\text { reuse, and recycle) in medium scale (e.g. Great Northern } \\
\text { Hydroponics (GNH), in Quebec: anaerobic digester - biogas } \\
\text { production-electricity to the farm), } \\
\checkmark \text { preventing the loss of rainwater that can be used to irrigate } \\
\text { vertical farms. } \\
\text { ADAPTATION TO CLIMATE CHANGE } \\
\checkmark \text { the possibility of creating spatial arrangements based on green } \\
\text { and blue infrastructure, e.g. water reservoirs, canals supporting } \\
\text { local biodiversity and having a direct impact on the } \\
\text { microclimate of residential districts, } \\
\checkmark \text { the possibility of using an irrigation system based on the reuse } \\
\text { of water based on the concept of a closed ecosystem at various } \\
\text { scales. }\end{array}$} & $\begin{array}{l}\checkmark \text { the possibility of creating new aquatic-plant-animal micro } \\
\text { habitats (e.g. aquaponic crops), } \\
\checkmark \text { sustainable food production by achieving the 3Rs (reduce, reuse, } \\
\text { and recycle) on a micro scale, } \\
\checkmark \text { On a local scale it's much more possible to create a self- sufficient } \\
\text { zero energy and zero waste system, } \\
\checkmark \text { the possibility of testing new green technologies supporting } \\
\text { vertical agriculture before introducing them to cities on a larger } \\
\text { scale, } \\
\checkmark \text { the possibility of using organic waste for the purposes of vertical } \\
\text { agriculture, } \\
\checkmark \text { improving the energy efficiency of buildings - reducing heat loss } \\
\text { and air conditioning costs by introducing vegetation on the } \\
\text { façade, } \\
\checkmark \text { protection of the building structure - protection against UV } \\
\text { radiation, temperature fluctuations. }\end{array}$ \\
\hline ADAPTATION TO CLIMATE CHANGE & & \multirow{3}{*}{$\begin{array}{l}\text { ADAPTATION TO CLIMATE CHANGE } \\
\checkmark \text { adaptation to climate change with the help of properly designed } \\
\text { "green" architecture, } \\
\checkmark \text { lower energy consumption by increasing the thermal insulation } \\
\text { properties of buildings. }\end{array}$} \\
\hline \multirow{3}{*}{$\begin{array}{l}\checkmark \text { creating an ecologically stable urban tissue resistant to climate } \\
\text { change and improving the quality of life, } \\
\text { vertical farms contribute to ecosystem services by mitigating } \\
\text { climate change, } \\
\text { eliminating the effect of the Urban Heat Island by introducing } \\
\text { agriculture in the form of green walls and green roofs on a city } \\
\text { scale. }\end{array}$} & & \\
\hline & LANDSCAPE & \\
\hline & \multirow{2}{*}{$\begin{array}{l}\checkmark \text { improvement of aesthetics in the scale of residential areas } \\
\text { thanks to new "green" architecture and bioarchitecture (e.g. } \\
\text { Bosco Verticale, Milan), } \\
\checkmark \text { the possibility of creating new aesthetics of residential districts } \\
\text { focused on green architecture and green urban planning, }\end{array}$} & \multirow{4}{*}{$\begin{array}{l}\text { LANDSCAPE } \\
\checkmark \text { making downtown buildings more attractive in the form of } \\
\text { green roofs and green facades, } \\
\text { the possibility of creating new canons of aesthetics in the form } \\
\text { of green architecture of multi-functional buildings (office } \\
\text { buildings, vertical eco-farms, catering services) - e.g. Plantagon, } \\
\text { Sweden). }\end{array}$} \\
\hline LANDSCAPE & & \\
\hline \multirow{3}{*}{$\begin{array}{l}\checkmark \text { improving the aesthetics of the city by building new "green" } \\
\text { panoramas of the city (e.g. Forest City, Malaysia, Green Paris } \\
2050) \text {, } \\
\checkmark \text { the possibility of creating new canons of aesthetics in the form } \\
\text { of green urbanism. }\end{array}$} & \multirow{5}{*}{$\begin{array}{l}\text { SUPPORT OF ECOLOGICAL CORRIDORS } \\
\checkmark \text { vertical greenery on the scale of the district maintains the } \\
\text { continuity of the system of ecological corridors (e.g. streets } \\
\text { greenery, pocket park system and others), } \\
\checkmark \text { thanks to aquaponic crops, it is possible to include vertical } \\
\text { farms and their immediate surroundings in the green-blue } \\
\text { infrastructure of housing estates. }\end{array}$} & \\
\hline & & \\
\hline & & SUPPORTING ECOLOGICAL CORRIDORS \\
\hline SUPPORT OF ECOLOGICAL CORRIDORS & & \\
\hline $\begin{array}{l}\checkmark \text { vertical greenery improves connectivity between the existing } \\
\text { urban green areas, prevents fragmentation and increases } \\
\text { ecological cohesion, } \\
\checkmark \text { a system of multifunctional vertical farms can create ecological } \\
\text { nodes for green and blue infrastructure. }\end{array}$ & & lawns, rain gardens). \\
\hline
\end{tabular}

Figure 3. Multi-scale environmental benefits resulting from the existence of vertical farms in the urban tissue (own elaboration). 


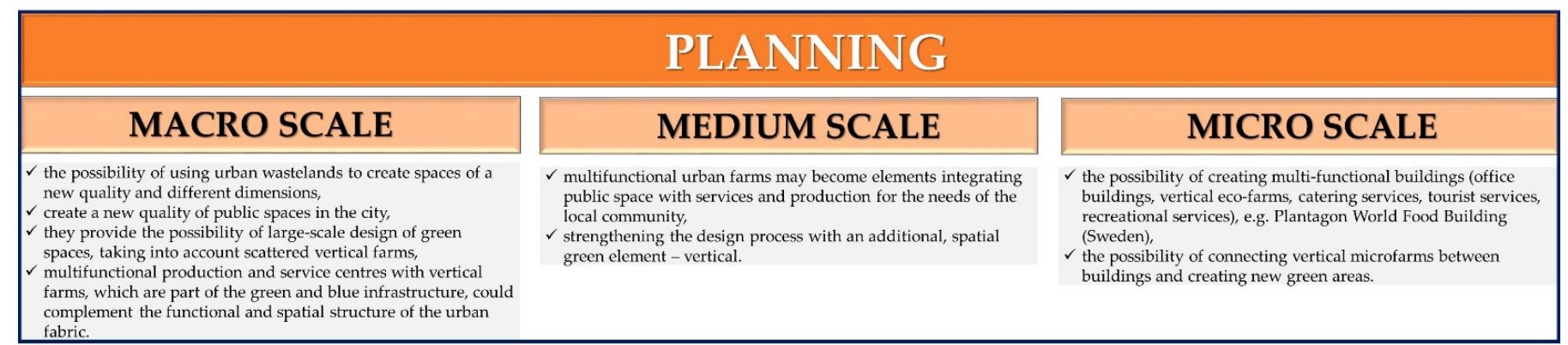

Figure 4. Multiscale benefits related to spatial planning resulting from the existence of vertical farms in the urban fabric (own elaboration).

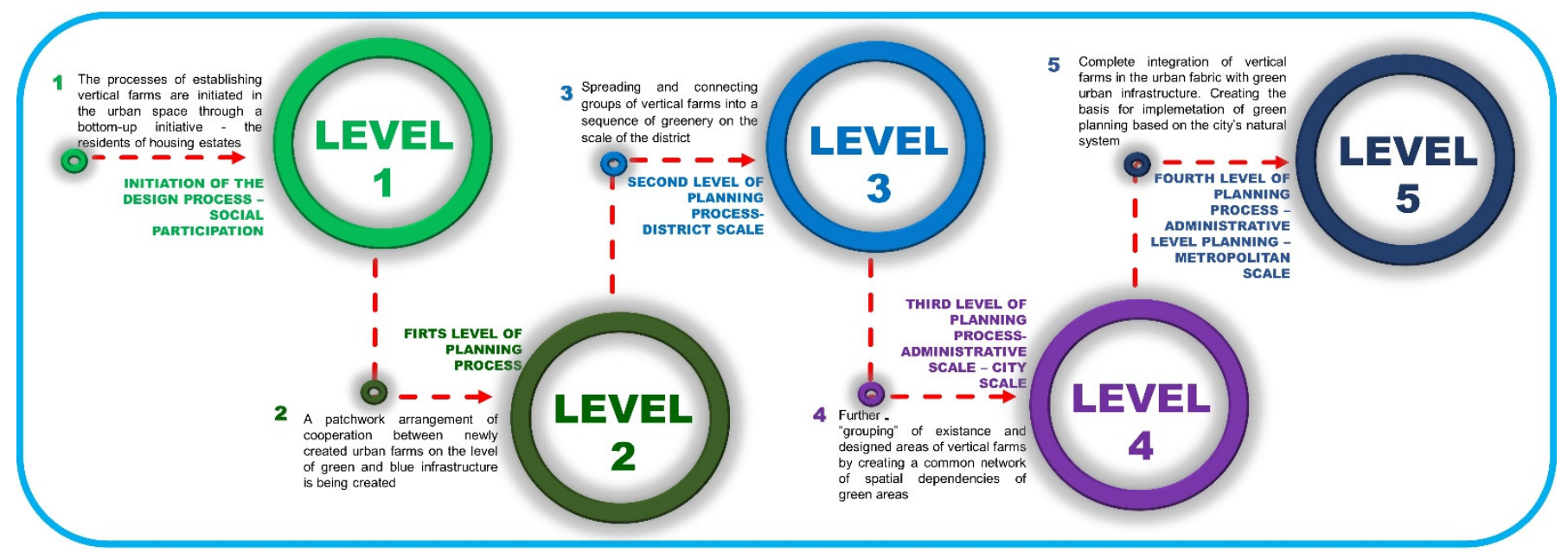

Figure 5. Pattern of vertical farms blending into the green infrastructure of the urban fabric in the process of space design (own elaboration).

Combining these areas in a 3D system and considering greenery in the urban fabric in a multi-dimensional (using vertical and horizontal planes) and multi-scale (i.e., on a micro-, medium-, and macro scale covering the urban fabric) method allows the modelling of various eco-farm solutions and the assigning of various service functions for the environment and people. Designing space in the cities of the post-pandemic era will have to take into account the preferences and needs of the entire community or some residents will suffer temporary isolation, limitations, or the need for nutritional self-sufficiency. This will consequently have an economic, social, environmental, and planning dimension (see Figures 1-4).

\section{Discussion}

Contemporary cities are turning towards creating strong, multi-functional residential districts, in line with the trends set by the concept of new urbanism. Especially in the postpandemic era, the creation of such spaces, in a self-sufficiency sense, seems particularly important. The integration of several functions in the structure of the municipal farm is in line with the trend of creating new social spaces that are friendly to urban residents. The productive function should therefore be supplemented with other functions useful for residents: the gastronomic sector, with the support of restaurants using vertical city farm products, or the recreational sector, by creating new public spaces associated with greenery $[67,68]$. An additional advantage here would be the possibility of adapting former industrial buildings and production halls for the needs of vertical urban agriculture. The functional and spatial programme of such places may be additionally strengthened by introducing other accompanying functions depending on the needs of the local community. Thanks to the use of greenery (utilitarian as well as decorative), the facilities, and area used 
for production should enable the performance of sports and recreational functions of the city's inhabitants, thus increasing the overall quality of their life in the city. In the future, it is possible that multifunctional city farms will become elements integrating public spaces with services and production for the local community. When programming the area around the city farm, it is reasonable to include the area of the city farm and its vicinity in the comprehensive green-blue infrastructure system. The design may include planning a water reservoir or a system of water reservoirs and canals that will increase local biodiversity and the attractiveness of vertical urban farms. The multifunctional production and service centres shaped in this way, i.e., an element of the green and blue infrastructure, could complement the functional and spatial structure of the urban fabric. New multifunctional vertical farms joined in integrated systems will allow the creation of an attractive and safe public space, allowing the full use of a given area, and thus may help prevent depopulation processes. This state of affairs will help to strengthen the physical and mental health of urban residents. An example of a new multi-functional vertical farm integrated directly into office buildings with the functionality of hydroponic farming is the World Food Building to be constructed in Linköping, Sweden, with the aim of producing at least 550 tons of vegetables every year. Food production in this vertical urban farm complies with the principle of $3 R$ (reduce, reuse, and recycle) whereby urban vertical farms produce a small amount of waste which is reused for soil fertilisation or for recycling. The prototype of the Plantscraper is based on a 12-story, mixed-use tower that houses an indoor farm along the green façade (The Planta Wall) [69]. Another example is the project of the Harvest Green Tower with multilayer, multi-functionality on different storys of the building with an underground system dedicated to a car park; street level for a grocery store, farmer's market, restaurants, and a transit hub; the lower floors are for animal farming; the middle floors create a space for producing fruit, vegetables, and fish; and the upper floors as a residential unit. The top and roof feature a large rainwater cistern $[37,70]$.

\section{Conclusions}

Sustainable development and care for the natural environment have an impact on modern cities. The new concept of a green economy is becoming more and more popular. The idea of local production is developing to meet the needs of cities. There is an urgent need in contemporary cities to reduce imports of goods that can be produced locally, promoting the local economy, and creating new jobs in urban farming. With the COVID19 pandemic, our lifestyle has changed (we are more isolated and we have learned to appreciate local products), and the development of remote working has benefited the environment and relieved the pressure on cities. The question now is how modern cities will be able to adapt to new social and environmental requirements.

Urban farms are our near future; they will not replace traditional agriculture, but vertical farms and cultivation with industrialised methods inside buildings will complement the alternative agricultural production system, offering a product with specific parameters created under controlled conditions. It is a flexible product which will be dependent on the current and changing needs of city dwellers. The research carried out for the purpose of this paper shows that work to increase efficiency from vertical cultivation and plant production methods is currently being implemented on different scales, from the city scale to the scale of buildings, and is carried out in the majority of cities which are dependent on food imports and with small amounts of agricultural land. Combining urban vertical farms in a multi-dimensional (multi-scale, multifunctional) system allows for modelling various design solutions for constantly developing cities. Newly created vertical urban farms will not only multiply harvests or reduce production costs in the future, but also significantly improve the quality of agricultural products provided to urban residents, and thus minimise the adverse impact of urbanisation on the environment. 
Author Contributions: Conceptualization, A.Z. and A.K.; methodology, A.Z., A.K. and R.K.; software, A.K.; validation, A.Z. and R.K.; formal analysis A.Z., A.K. and R.K.; investigation, A.Z., A.K. and R.K.; resources, A.Z., A.K. and R.K.; data curation, A.Z., A.K. and R.K.; writing-original draft preparation, A.Z., A.K. and R.K.; writing-review and editing, A.Z., A.K. and R.K.; visualization, A.K., supervision, A.Z.; project administration, A.Z. and A.K. funding acquisition, R.K. All authors have read and agreed to the published version of the manuscript.

Funding: This research received no external funding.

Institutional Review Board Statement: Not applicable.

Informed Consent Statement: Not applicable.

Data Availability Statement: Data is contained within the article.

Conflicts of Interest: The authors declare no conflict of interest.

\section{References}

1. The United Nations. World Population Prospects: The 2017 Revision; United Nations: New York, NY, USA, 2017.

2. Eigenbrod, C.; Gruda, N. Urban vegetable for food security in cities. A review. Agron. Sustain. Dev. 2015, 35, 483-498. [CrossRef]

3. Chen, J. Rapid urbanization in China: A real challenge to soil protection and food security. Catena 2007, 69, 1-15. [CrossRef]

4. Muller, A.; Ferré, M.; Engel, S.; Gattinger, A.; Holzkämper, A.; Huber, R.; Müller, M.; Six, J. Can soilless crop production be a sustainable option for soil conservation and future agriculture? Land Use Policy 2017, 69, 102-105.

5. Healy, R.G.; Rosenberg, J.S. Land Use and the States; Routledge: New York, NY, USA, 2013.

6. Despommier, D. The Vertical Farm: Feeding the World in the 21st Century; Macmillan: Basingstoke, UK, 2010.

7. Despommier, D. Farming up the city: The rise of urban vertical farms. Trends Biotechnol. 2013, 31, 388-389. [CrossRef]

8. Maughan, T. Is Farming the Future of Cities? Eng. Technol. 2016, 10, 56-59. [CrossRef]

9. Specht, K.; Siebert, R.; Hartmann, I.; Freisinger, U.B.; Sawicka, M.; Werner, A.; Thomaier, S.; Henckel, D.; Walk, H.; Dierich, A. Urban agriculture of the future: An overview of sustainability aspects of food production in and on buildings Agric. Hum. Values 2014, 31, 33-51. [CrossRef]

10. La Rosa, D.; Barbarossa, L.; Privitera, R.; Martinico, F. Agriculture and the city: A method for sustainable planning of new forms of agriculture in urban contexts. Land Use Policy 2014, 41, 290-303. [CrossRef]

11. Benke, K.; Tomkins, B. Future food-production systems: Vertical farming and controlled-environment agriculture. Sustain. Sci. Pract. Policy 2017, 13, 13-26. [CrossRef]

12. Martins, M.T.; de Campos, I.D. From the Horizontal Garden to the Vertical Garden: An Architectural and Environmental Perspective of the "Green" Element Ana 2018; IOP Conference Series: Materials Science and Engineering; IOP Publishing: Bristol, UK, 2019; Volume 471, p. 072022. [CrossRef]

13. Hindle, R.L. A vertical garden: Origins of the Vegetation-Bearing Architectonic Structure and System (1938). Stud. Hist. Gard. Des. Landsc. 2012, 32, 99-110. [CrossRef]

14. Rees, G. An unpublished manuscript by Francis Bacon: Sylva Sylvarum drafts and other working notes. Ann. Sci. 1981, 38, 377-412. [CrossRef]

15. Jahnkassim, P.S.; Kenneth, I. Linking bioclimatic theory and environmental performance in its climatic and cultural context-An analysis into the tropical highrises of Ken Yeang. In Proceedings of the PLEA2006-The 23rd Conference on Passive and Low Energy Architecture, Geneva, Switzerland, 6-8 September 2006.

16. Sartor, J.; Mobilia, M.; Longobardi, A. Results and findings from 15 years of sustainable urban storm water management. J. Saf. Secur. Eng. 2018, 8, 505-514. [CrossRef]

17. Fletcher, T.D.; Shuster, W.; Hunt, W.F.; Ashley, R.; Butler, D.; Arthur, S.; Trowsdale, S.; Barraud, S.; Semadeni-Davies, A.; Bertrand-Krajewski, J.L.; et al. SUDS, LID, BMPs, WSUD and more-The evolution and application of terminology surrounding urban drainage. Urban Water J. 2015, 12, 525-542. [CrossRef]

18. Patro, M.; Koper, A. Ogrody wertykalne jako efektowny element zieleni w krajobrazie zurbanizowanym. Bud. I Archit. 2016, 15, 145-154. [CrossRef]

19. Westphal, L.M. Social Aspects of Urban Forestry. Urban Greening and Social Benefits: A Study of Empowerment Outcomes. J. Arboric. 2003, 29, 137-147.

20. Kalantari, F.; Mohd tahir, O.; Joni, R.A.; Fatemi, E. Opportunities and Challenges in Sustainability of Vertical Farming: A Review. J. Landsc. Ecol. 2017, 11, 35-60. [CrossRef]

21. Despommier, D. Encyclopedia of Food and Agricultural Ethics (Vertical Farms in Horticulture); Springer: Dordrecht, The Netherlands, 2014.

22. Harris, D. Hydroponics: A Practical Guide for the Soilless Grower, 2nd ed.; New Holland Publishing: London, UK, 1992.

23. Graber, A.; Schoenborn, A.; Junge, R. Closing water, nutrient and energy cycles within cities by urban farms for fish and vegetable Production. Int. Water Assoc. Newsl. 2011, 37, 37-41. 
24. Diver, S. Aquaponics - Integration of Hydroponics with Aquaculture, National Sustainable Agriculture Information Service. 2006. Available online: http:/ / www.backyardaquaponics.com/Travis/aquaponic.pdf (accessed on 15 June 2021).

25. Goddek, S.; Joyce, A.; Kotzen, B.; Burnell, D. Aquaponics Food Production Systems: Combined Aquaculture and Hydroponic Production Technologies for the Future; Springer International Publishing: Berlin/Heidelberg, Germany, 2019.

26. Agnotti, T. Urban agriculture: Long-term strategy or impossible dream? Lessons from Prospect Farm in Brooklyn, New York. Public Health 2015, 129, 336-341.

27. Sabeh, N. Rooftop plant production systems in urban areas. In Plant Factory. An Indoor Vertical Farming System for Efficient Quality Food Production; Kozai, T., Niu, G., Takagaki, M., Eds.; Academic Press: Cambridge, MA, USA, 2015; Volume 23, pp. $105-111$.

28. Jim, C.Y.; Peng, L.H. Weather effects on thermal and energy performance of an extensive tropical green roof. Urban For. Urban Green. 2012, 11, 73-85. [CrossRef]

29. Tam, V.W.Y.; Wang, J.; Lea, K.N. Thermal insulation and cost effectiveness of green-roof systems: An empirical study in Hong Kong. Build. Environ. 2016, 110, 46-54. [CrossRef]

30. Ng, E.; Chen, L.; Wang, Y.; Yuan, C. A study on the cooling effects of greening in a high-density city: An experience from Hong Kong. Build. Environ. 2012, 47, 256-271. [CrossRef]

31. Castleton, H.F.; Stovin, V.; Beck, S.B.M.; Davison, J.B. Green roofs; building energy savings and the potential for retrofit. Energy Build. 2010, 42, 1582-1591. [CrossRef]

32. Theodosiou, T.G. Summer period analysis of the performance of a planted roof as a passive cooling technique. Energy Build. 2003, 35, 909-917. [CrossRef]

33. Fioretti, R.; Palla, A.; Lanza, L.G.; Principi, P. Green roof energy and water-related performance in the Mediterranean climate. Build. Environ. 2010, 45, 1890-1904. [CrossRef]

34. Suszanowicz, D.; Ratuszny, P.; Wróbel, R. The potential of roofs in city centers to be used for photovoltaic micro-installations. IOP Conf. Ser. Mater. Sci. Eng. 2019, 564, 012128. [CrossRef]

35. Ascione, F.; Bianco, N.; de' Rossi, F.; Turni, G.; Vanoli, G.P. Green roofs in European climates. Are there effective solutions for the energy savings in air-conditioning? Appl. Energy 2013, 104, 845-859.

36. Akbari, H.; Konopacki, S. Energy effects of heat-island reduction strategies in Toronto, Canada. Energy 2004, 29, 191-210. [CrossRef]

37. Al-Kodmany, K. The Vertical Farm: A Review of Developments and Implications for the Vertical City. Buildings 2018, 8, 24. [CrossRef]

38. Perez-Urrestarazu, L.; Cañero-Fernandez, R.; Franco-Salas, A.; Egea, G. Vertical Greening Systems and Sustainable Cities. J. Urban Technol. 2015, 22, 65-85. [CrossRef]

39. Ksit, B.; Majcherek, M. Green Walls, czyli zielone ściany jako ekologiczne przegrody budowlane-cz. I Inżynier Budownictwa 2013, 6, 120-122. Available online: https:/ / inzynierbudownictwa.pl/green-walls-czyli-zielone-sciany-jako-ekologiczne-przegrodybudowlane-cz-i/ (accessed on 10 August 2021).

40. Zeidler, C.; Schubert, D.; Vrakking, V. Vertical Farm 2.0: Designing an Economically Feasible Vertical Farm-A Combined European Endeavor for Sustainable Urban Agriculture; German Aerospace Center: Cologne, Germany, 2015.

41. Perini, K.; Ottelé, M. Designing green façades and living wall systems for sustainable constructions. Int. J. Des. Nat. Ecodynamics 2014, 9, 31-46. [CrossRef]

42. Bartfelder, F.; Köhler, M. Experimentelle Untersuchungenzur Funktionvon Fassadenbegrunungen; Förderungsprogramm Der Freien Univ. Berl. Fur Junge Wiss 3 Ausschreib; 1987.

43. Wong, N.H.; Tan, A.Y.K.; Tan, P.Y.; Chiang, K.; Wong, N.C. Thermal evaluation of vertical greenery systems for building walls. Build. Environ. 2009, 45, 663-672. [CrossRef]

44. Thomaier, S.; Specht, K.; Henckel, D.; Dierich, A.; Siebert, R.; Freisinger, U.B.; Sawicka, M. Farming in and on Urban Buildings: Present Practice and Specific Novelties of Zero-Acreage Farming (ZFarming). Renew. Agric. Food Syst. 2015, 30, 43-54. [CrossRef]

45. United States Environmental Protection Agency. AgSTAR: Biogas Recovery in the Agriculture Sector. Available online: https: //www.epa.gov / agstar (accessed on 15 June 2021).

46. Daniel, P. Contribution of Vertical Farms to Increase the Overall Energy Efficiency of Urban Agglomerations. J. Power Energy Eng. 2014, 2, 82-85. [CrossRef]

47. Pattison, P.; Lee, K.; Stober, K.; Yamada, M. Energy Savings Potential of SSL in Horticultural Applications; EERE Publication and Product Library: Washington, DC, USA, 2017. [CrossRef]

48. Gottero, E. Approaching a Vision of Agrarian Urbanism: Innovative Domains, Key Definitions and Concepts. In Agrourbanism. Tools for Governance and Planning of Agrarian Landscape; Gottero, E., Ed.; Springer: Berlin/Heidelberg, Germany, 2019.

49. Pettenati, G. Urban Agriculture in Urban Food Policies: Debate and Practices. In Agrourbanism. Tools for Governance and Planning of Agrarian Landscape; Gottero, E., Ed.; Springer International Publishing: Berlin/Heidelberg, Germany, 2019; pp. 171-185.

50. Parham, S. Foodscape and Food Urbanism in Europe: The Urban-Rural Interface. In Agrourbanism. Tools for Governance and Planning of Agrarian Landscape; Gottero, E., Ed.; Springer International Publishing: Berlin/Heidelberg, Germany, 2019 ; pp. 109-129.

51. Grydehoj, A.; Kelman, I. Island Smart Eco-Cities: Innovation, Secessionary Enclaves, and the Selling of Sustainability. Urban Isl. Stud. 2016, 2. [CrossRef]

52. Moser, S.; Avery, E. The multi-scalar politics of urban greening in Forest City, Malaysia. Urban For. Urban Green. 2021, 60, 1-5. [CrossRef] 
53. Farhangi, M.; Turvani, M.; van der Valk, A.; Carsjens, G. Technology-Driven Transition in Urban Food Production Practices: A Case Study of Shanghai. Sustainability 2019, 11, 6070. [CrossRef]

54. Shi, K.; Chen, Y.; Yu, B.; Xu, T.; Li, L.; Huang, C.; Liu, R.; Chen, Z.; Wu, J. Urban expansion and agriculturalland loss in China: A multiscale perspective. Sustainability 2016, 8, 790. [CrossRef]

55. Perkins, D.H. Agricultural Development in China, 1368-1968; Routledge: New York, NY, USA, 2017.

56. Sasaki. Sunqiao Urban Agricultural District. Available online: http://www.sasaki.com/project/417/sunqiao-urban-agriculturaldistrict/ (accessed on 15 June 2021).

57. Zhao, J. Exploration and practices of China's urban development models. In Towards Sustainable Cities in China; Springer: New York, NY, USA, 2011; pp. 15-36.

58. Lee, K.; Elliott, C.; Pattison, P. Energy Savings Potential of SSL in Agricultural Applications; US Department of Energy: Washington, DC, USA, 2020. [CrossRef]

59. Wang, J. The Sprouting Farms: You Are What You Grow. Humanities 2021, 10, 27. [CrossRef]

60. Advantages of Vertical Farming. Vertical Farming Systems. 2017. Available online: http://www.verticalfarms.com.au/ advantages-vertical-farming (accessed on 15 June 2021).

61. Proksh, G. Sustainably integrated infrastructure: Synergies between water management and agricultural practices. Int. J. Environ. Sustain. 2012, 1, 1-11.

62. Miner, R.C.; Raftery, S. Turning brownfields into "green fields": Growing food using marginal lands. WIT Trans. Ecol. Environ. 2012, 162, 413-419.

63. Kleszcz, J.; Kmiecik, P.; Świerzawski, J. Vegetable and Gardening Tower of Othmar Ruthner in the Voivodeship Park of Culture and Recreation in Chorzów-The First Example of Vertical Farming in Poland. Sustainability 2020, 12, 5378. [CrossRef]

64. Ministerstwo, Ś. Opracowanie planów adaptacji do zmian klimatu w miastach powyżej 100 tys. Mieszkańców. Available online: https:/ / mapadotacji.gov.pl/projekty/746239/ (accessed on 15 June 2021).

65. Zarząd Zieleni Miejskiej w Krakowie. Available online: https://zzm.krakow.pl/parki-kieszonkowe.html (accessed on 15 June 2021).

66. Zachariasz, A. Zielony Kraków: Dla przyjemności i pożytku Sznownej Publiczności; Wydawnictwo Politechniki Krakowskiej: Kraków, Poland, 2019.

67. Grewal, S.S.; Grewal, P.S. Can cities become self-reliant in food? Cities 2012, 29, 1-11. [CrossRef]

68. Voss, P.M. Vertical Farming: An agricultural revolution on the rise. Halmstad. 2013. Available online: https:/ / www.diva-portal. org/smash/record.jsf?pid=diva2\%3A628988\&dswid=-3654 (accessed on 10 August 2021).

69. Scnitzher, W.H. Urban Hydroponics for Green and Clean Cities and for Food Security. Acta Hortic 2012, 1004, 13-26.

70. Jordana, S. Harvest Green Project/Romses Architects. ArchDaily, 7 May 2009. Available online: http://www.archdaily.com/2155 5/harvest-green-project-romses-architects / (accessed on 15 June 2021). 